\title{
Piezoelectric Unimorphs Dynamic Response Measurement
}

\author{
Jana Koucká ${ }^{1}$; Petr Půlpán; Martin Pustka \\ VÚTS, a.s., Measurement Department, \\ Svárovská 619, Liberec XI - Růžodol I, 46001 Liberec, Czech Republic \\ e-mail: ${ }^{1}$ jana.koucka@vuts.cz
}

\begin{abstract}
The paper deals with the experimental methods of determination of piezoelectric unimorph resonant frequencies essential for a design of acoustical systems. The characterization of piezoelectric unimorphs and their significant properties are brought in. Three broadband methods of determination of unimorph frequency response based on measurement of electrical impedance, acoustic pressure and vibration velocity are presented. The supposed methodology is verified by measurement of three unimorph samples. The efficiency and practical applicability of each method are further discussed.
\end{abstract}

\section{Keywords}

Piezoelectric unimorph; Resonant frequency; Measurement; Impedance; Acoustic pressure; Vibration velocity.

\section{Introduction}

The piezoelectric unimorphs are electro-mechanical or electro-acoustical transducers composed of one piezoelectric and one flexible (usually metallic) layer. They have a wide range of applications as actuators or sensing elements and are commonly utilized in micropumps [1], flow control actuators [2] or energy harvesting systems [3]. The main application field is represented by speakers and buzzers in acoustical systems [4], [5] at working frequency of $100 \mathrm{~Hz}$ to $10 \mathrm{kHz}$.

Due to tolerances of piezoelectric material properties and production tolerances, the unimorphs of the same type and dimension have relatively large variation of resonant frequencies. For a design of resonant acoustical systems it is necessary to determine the natural frequency as accurately as possible. The frequency calculations using analytical methods or FEM have a lower accuracy and the most preferred method is measurement.

The operating principle is based on the inverse piezoelectric effect with mechanical-acoustical energy conversion. The unimorph behaves simultaneously as an electrical, mechanical and acoustical oscillator and its resonant frequency can be determined by the measurement of electrical, mechanical or acoustical quantities. In the resonance the electrical impedance has its minimum, whereas the acoustic pressure and vibration velocity generated by the unimorph are on its maxima.

In following three experimental methods for determination of unimorph natural frequency are presented and their efficiency and applicability is discussed.

\section{$1 \quad$ Piezoelectric Unimorph}

The piezoelectric unimorph is composed of piezoelectric ceramic disc bonded to the nonpiezoelectric (mostly metallic) carrier (Figure 1). The unimorphs are usually mounted at the 
circumference (diameter $d_{m}$ ) by clamping or hinge-connection, the mounting in the disc center is less frequent.

Mechanical deformation is generated by the electric field applied to the electrodes. For resonant acoustical systems the driving electric field has a frequency close to the unimorph natural frequency.

Source: Own

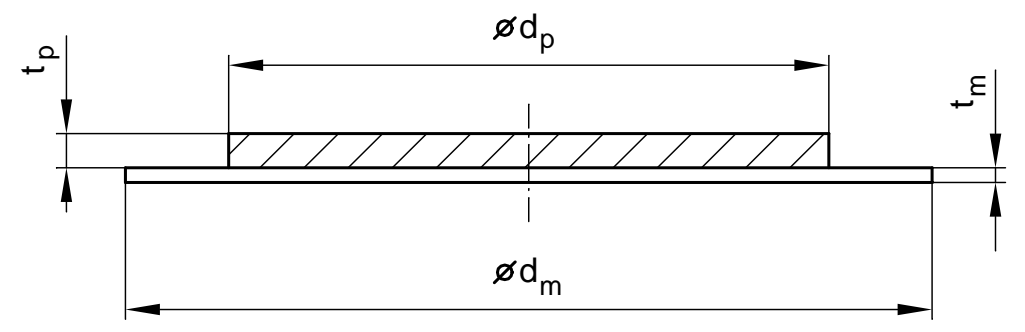

Fig. 1: Piezoelectric unimorph cross section

Considering the axial symmetry of unimorph and electric field the piezoelectric disc vibrates in extensional axisymmetric vibrations [6]. This results in the axisymmetric flexural deformation of the unimorph structure having nodal circles only with the highest deflection in the center. The four lowest mode shapes of circumferentially clamped unimorph are schematically shown in Figure 2.

However, the non-axisymmetric modes having also nodal lines can be excited as an effect of small unbalances (in mounting, piezoceramic and metal layers alignment etc.). These modes have lower amplitude response when compared with the "pure" modes.
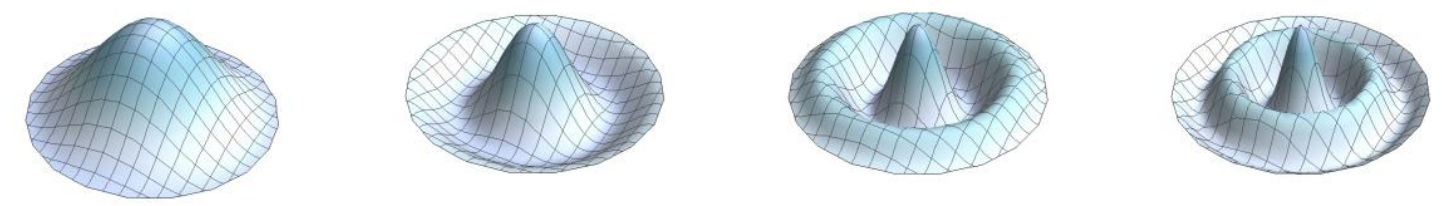

Source: Own

Fig. 2: Four lowest mode shapes of circumferentially clamped unimorph (increasing from left to right)

\section{Measurement and Evaluation Description}

Three APC unimorph samples with APC 855 piezoceramic layer and brass metallic layer were used for the experiments. The sample dimensions are given in Table 1. Screen-printed silver electrodes have negligible influence on unimorph performance.

Tab. 1: Unimorph samples dimensions

\begin{tabular}{|l|c|c|c|c|c|}
\hline Sample & Unimorph type & $\begin{array}{c}\sigma d_{\boldsymbol{p}}[\mathbf{m m}] \\
\text { ceramics }\end{array}$ & $\begin{array}{c}\sigma d_{\boldsymbol{m}}[\mathbf{m m}] \\
\text { brass }\end{array}$ & $\begin{array}{c}\boldsymbol{t}_{\boldsymbol{p}}[\mathbf{m m}] \\
\text { ceramics }\end{array}$ & $\begin{array}{c}\boldsymbol{t}_{\boldsymbol{m}}[\mathbf{m m}] \\
\text { brass }\end{array}$ \\
\hline 1 & $20-1060$ & 25 & 38 & 0.10 & 0.10 \\
\hline 2 & $20-1230$ & 25 & 38 & 0.10 & 0.10 \\
\hline 3 & $20-1225$ & 25 & 34 & 0.25 & 0.30 \\
\hline
\end{tabular}

Source: Own

The samples were mounted in a laboratory fixture clamped between two rubber o-rings and pulled over the flanges by screws. This mounting type corresponds to a rigid clamping at the 
circumference $d_{m}$. The fixture with unimorph was placed on an absorbent pad to prevent the reflection of acoustic waves from the back side.

At first the frequency spectrum of impedance (amplitude and phase) was determined using impedance analyzer HP 4294 for each sample in the frequency range to $4 \mathrm{kHz}$. The amplitude of the exciting voltage was $1 \mathrm{~V}$.

Then the frequency dependences of acoustic pressure and vibration velocity of the unimorph were measured simultaneously. The acoustic pressure was measured at a distance of $0.9 \mathrm{~m}$ above the unimorph plane in the unimorph axis with the BK 4961 measurement microphone. The vibration velocity of the unimorph center was measured using vibration analyzer Polytec PDV-100. The samples were excited by a harmonic signal with amplitude $1 \mathrm{~V}$ swept at rate $3.8 \mathrm{kHz} / \mathrm{s}$ in the frequency range of $200 \mathrm{~Hz}$ to $4 \mathrm{kHz}$. The signals were processed by a measurement system BK PULSE.

To suppress the noise in the measured data, all measurement were repeated several times and the results averaged. The frequency dependences of acoustic pressure and vibration velocity are processed in form of a frequency response function $H$, i.e. as a normalized spectrum divided by a spectrum of exciting voltage.

\section{$3 \quad$ Results and Discussion}

The frequency spectra of impedance, acoustic pressure and vibration velocity for a unimorph sample 20-1230 in the frequency range of $200 \mathrm{~Hz}$ to $4 \mathrm{kHz}$ are shown in Figures 3 to 5. The resonant frequencies corresponding to minima of electrical impedance amplitude or maxima of sound pressure and vibration velocity are clearly evident. The resonant frequencies determined from the measured spectra are listed in Tables 2 to 4 for all samples.

In the frequency range to $4 \mathrm{kHz}$ four resonant frequencies were estimated for samples 201060 and 20-1230 and three for the sample 20-1225. The frequency values are very close for all three measurement methods.

The frequencies corresponding to the sound pressure and vibration velocity are almost equal for samples 20-1060 and 20-1230, which confirms the maximum energy transfer at resonance. In the sample 20-1225, the velocity and acoustic pressure maxima differ significantly. The discrepancy is brought by a poor quality acoustical frequency response with broad peaks.

Natural frequencies corresponding to maximum impedance values have lower values than those obtained from acoustic pressure and vibration velocity. This phenomenon is typical for resonators with a low mechanical factor [7] as in the case of unimorphs.

The vibration velocity was measured at the center of a unimorph. Absolute amplitude values at various frequencies cannot be directly compared since the mode shapes have a complex shape (see Figure 2).

Tab. 2: Measured resonant frequencies [Hz], unimorph sample 20-1060

Source: Own

\begin{tabular}{|l|l|l|l|l|}
\hline Impedance & 690 & 1050 & 2780 & 3470 \\
\hline Acoustic pressure & 706 & 1068 & 2815 & 3523 \\
\hline Vibration velocity & 707 & 1073 & 2828 & 3520 \\
\hline
\end{tabular}


Tab. 3: Measured resonant frequencies [Hz], unimorph sample 20-1230

Source: Own

\begin{tabular}{|l|l|l|l|l|}
\hline Impedance & 650 & 1010 & 2630 & 3290 \\
\hline Acoustic pressure & 653 & 1031 & 2686 & 3343 \\
\hline Vibration velocity & 652 & 1035 & 2687 & 3348 \\
\hline
\end{tabular}

Tab. 4: Measured resonant frequencies [Hz], unimorph sample 20-1225

Source: Own

\begin{tabular}{|l|l|l|l|}
\hline Impedance & 888 & 1495 & 3408 \\
\hline Acoustic pressure & 912 & 1745 & 3758 \\
\hline Vibration velocity & 892 & 1550 & 3445 \\
\hline
\end{tabular}
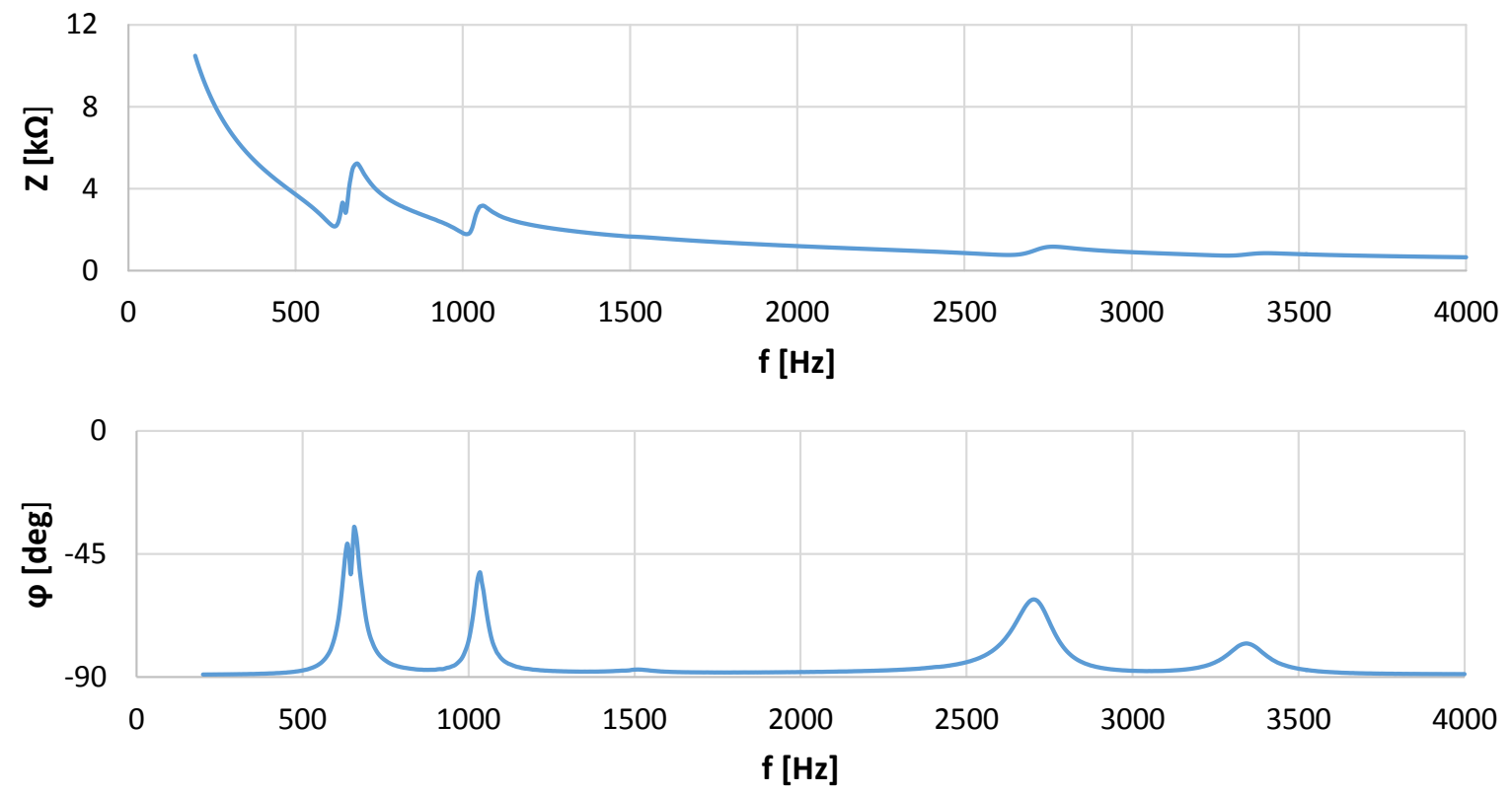

Source: Own

Fig. 3: Impedance frequency spectrum, unimorph sample 20-1230

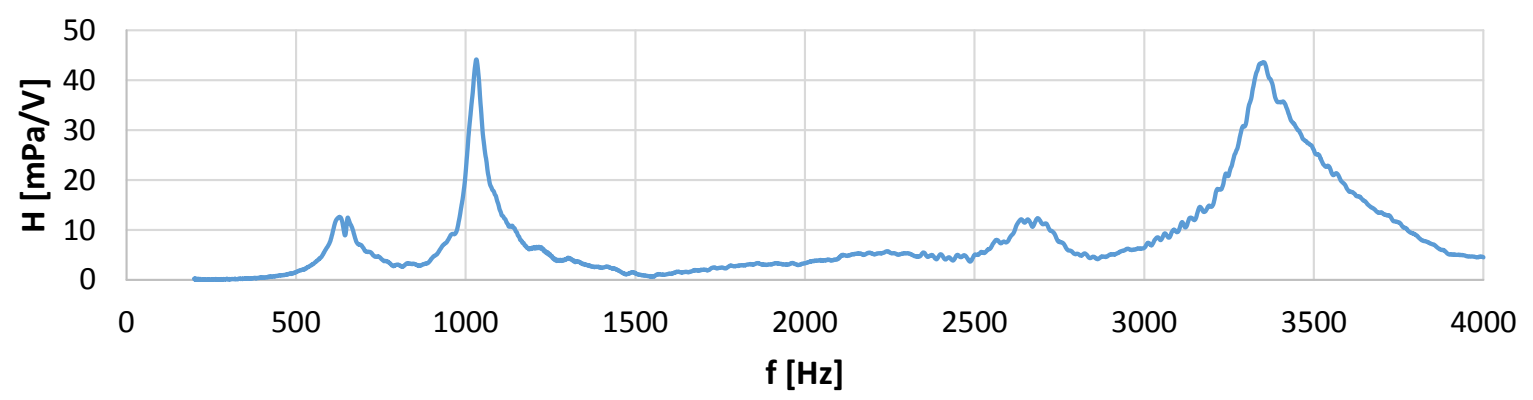

Source: Own

Fig. 4: Acoustic pressure frequency response function, unimorph sample 20-1230 


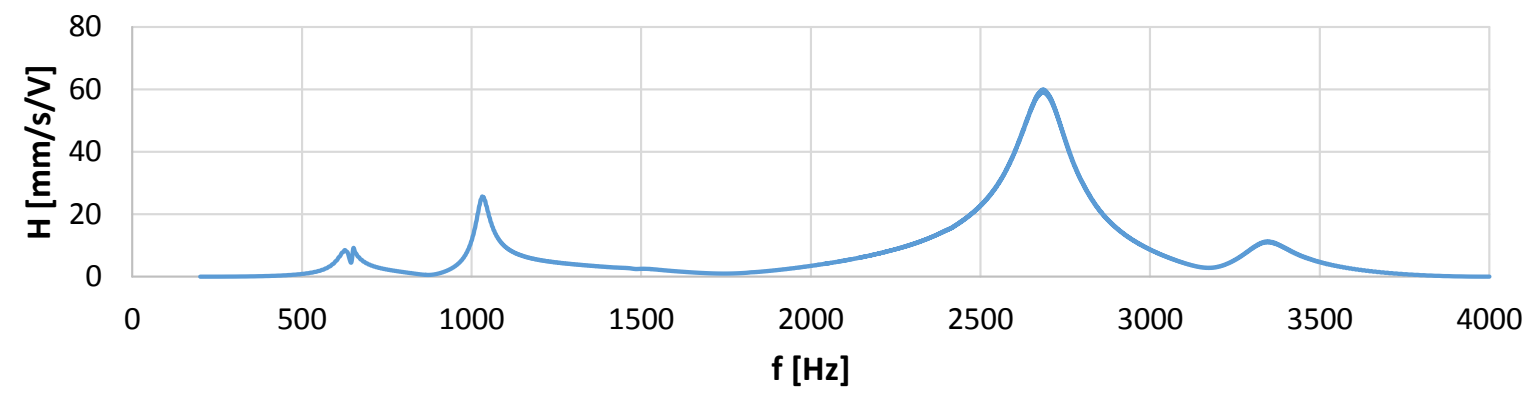

Source: Own

Fig. 5: Vibration velocity frequency response function, unimorph sample 20-1230

\section{Conclusion}

The reliable determination of unimorph resonant frequency is critical for a design of acoustical systems. Three broadband experimental methods for the determination of resonant frequency based of measurement of electrical impedance, acoustic pressure and vibration velocity were presented.

The best and consistent results were achieved by the measurement of electrical impedance and vibrational velocity. The measurement of acoustic pressure is influenced by the quality of unimorph noise emission and requires suitable acoustic conditions with low background noise level.

\section{Acknowledgements}

This work was supported by the Czech Ministry of Education, project LO1213.

\section{Literature}

[1] MORRIS, C. J.; FORSTER, F. K.: Optimization of a Circular Piezoelectric Bimorph for a Micropump Driver. Journal of Micromechanics and Microengineering. 2000, Volume 10, Issue 3, pp. 459-465.

[2] UCHINO, K.: Ferroelectric Devices. $2^{\text {nd }}$ edition. CRC Press, Boca Raton, 2009. ISBN 978-1-4398-0375-2.

[3] ERICKA, M. et al.: Energy Harvesting from Vibration Using a Piezoelectric Membrane. Journal de Physique IV. 2005, Volume 128, pp. 187-193.

[4] BOST, J. R.: A New Piezoelectric Driver Enhances Horn Performance. Journal of the Audio Engineering Society. 1980, Volume 28, Issue 4, pp. 244-249.

[5] MENDOZA-LÓPEZ, J. et al.: Characterization and Modelling of Circular Piezoelectric Micro Speakers for Audio Acoustic Actuation. ISRN Mechanical Engineering. 2012. DOI: $10.5402 / 2012 / 635268$.

[6] BERLINCOURT, D. A. et al.: Piezoelectric and Piezomagnetic Materials and Their Function in Transducers. In: Mason, W. P. (ed.), Physical Acoustics - Principles and Methods, Volume 1-A: Methods and Devices. Chapter 3, pp. 169-270. Academic Press, New York, 1964.

[7] ZELENKA, J.: Piezoelectric Resonators and Their Applications. Elsevier, Amsterdam, 1986. ISBN 978-0-444-99516-2.

Ing. Jana Koucká; Ing. Petr Půlpán, Ph.D.; Ing. Martin Pustka, Ph.D. 


\section{MĚŘENÍ DYNAMICKÉ ODEZVY PIEZOELEKTRICKÝCH UNIMORFŮ}

Článek se zabývá experimentálními metodami stanovení vlastních frekvencí piezoelektrických unimorfu, které jsou důležité pro navrhování akustických systémů. Stručně jsou představeny piezoelektrické unimorfy a jejich významné vlastnosti. Uvádí se tři širokopásmové měřicí metody založené na měřní elektrické impedance, akustického tlaku a rychlosti kmitání. Navržené metodiky jsou ověřeny měřením na třech vzorcích unimorfü. V závěru je zhodnocena efektivita a praktická využitelnost jednotlivých metod.

\section{MESSUNGEN VON DYNAMISCHEN EIGENSCHAFTEN DER PIEZOELEKTRISCHEN UNIMORPHS}

Der Artikel befasst sich mit den experimentellen Methoden zur Bestimmung der Resonanzfrequenzen von piezoelektrischen Unimorphs, die für den Entwurf von akustischen Systemen wesentlich sind. Die piezoelektrischen Unimorphs und ihre bedeutenden Eigenschaften werden angegeben. Drei Breitbandmethoden basierend auf der Messung der elektrischen Impedanz, Schalldruck und Vibrationsgeschwindigkeit werden vorgestellt. Die vermeintliche Methodik wird durch Messung von drei Unimorphproben verifiziert. Abschließend werden die Effizienz und die praktische Anwendbarkeit der einzelnen Methoden diskutiert.

\section{POMIAR DYNAMICZNEJ ODPOWIEDZI UNIMORFÓW PIEZOELEKTRYCZNYCH}

Artykuł poświęcony jest eksperymentalnym metodom określania własnych częstotliwości unimorfów piezoelektrycznych, które są istotne przy projektowaniu systemów akustycznych. Krótko opisano unimorfy piezoelektryczne oraz ich najważniejsze właściwości. Wskazano trzy szerokopasmowe metody pomiaru oparte na pomiarze impedancji elektrycznej, ciśnienia akustycznego oraz szybkości drgań. Zaproponowane metodyki sprawdzono przy pomocy pomiarów na trzech próbkach unimorfów. W zakończeniu opracowania opisano efektywność i możliwości praktycznego zastosowania poszczególnych metod. 